\title{
Loss of idealism or realistic optimism? A cross-sectional analysis of dental hygiene students' and registered dental hygienists' professional identity perceptions
}

\author{
JM Champine $^{1}$ | MR Inglehart ${ }^{2,3}$ D | D Furgeson ${ }^{2}$ | JF Halaris ${ }^{2}$ | M Fitzgerald ${ }^{4}$ | \\ TE Danciu $^{2}$ | JS Kinney ${ }^{2}$
}

${ }^{1}$ Health and Human Services Division, Lansing Community College, Lansing, MI, USA

${ }^{2}$ Department of Periodontics and Oral Medicine, School of Dentistry, University of Michigan, Ann Arbor, MI, USA

${ }^{3}$ Department of Psychology, College of Literature, Science and Arts (LS\&A), University of Michigan, Ann Arbor, MI, USA

${ }^{4}$ Department of Cariology, Restorative Sciences, and Endodontics, School of Dentistry, University of Michigan, Ann Arbor, MI, USA

\section{Correspondence}

Dr. Marita R. Inglehart, Department of Periodontics and Oral Medicine, School of Dentistry, University of Michigan, Ann Arbor, MI, USA.

Email: mri@umich.edu

\section{Funding information}

This research was supported by a University of Michigan - Rackham Graduate Student Research Grant and Research Block Grant to the first author.

\begin{abstract}
Objectives: The dental hygiene profession in the U.S. is in the process of establishing a direct access model of care and contributing to the creation of the profession of a dental therapist. The objectives were to analyse the professional role perceptions of dental hygiene students and registered dental hygienists in these times of change. Specifically, it was explored whether dental hygiene students' current professional identities differ (i) from their expected future identities, and (ii) from dental hygienists' current and (iii) past identities.

Methods: Survey data were collected from 215 dental hygiene students concerning their present and future role perceptions, and from 352 registered dental hygienists concerning their present and past professional identity perceptions.

Results: Students' future professional identity perceptions were even more positive than their very positive current perceptions of their professional role components. Students' current perceptions of professional pride, professional ambition, work ethic and patient relations were more positive than dental hygienists' current perceptions of these professional role components. A comparison of students' current perceptions with dental hygienists' current and retrospective descriptions showed that students were more positive than dental hygienists in each case.

Conclusions: The fact that dental hygienists had less positive role perceptions than dental hygiene students might lead to the conclusion that a loss of idealism occurs over the course of a professional lifespan. However, dental hygienists actually improved their role perceptions over time and students' future descriptions were more positive than their current descriptions, supporting the interpretation that realistic optimism dominates professional role perceptions in these times of change.
\end{abstract}

\section{KEYWORDS}

attitudes, dental hygiene profession, dental hygienist, motivation, professional identity

\section{1 | INTRODUCTION}

The dental hygiene profession in the United States (U.S.) had its beginnings in the 19 th century $^{1}$ when the term "dental hygienist" was first used officially in the U.S. about a century ago in 1913. ${ }^{2,3}$ Dental hygienists in all U.S. states are licensed healthcare providers who must have graduated from one of 334 accredited dental hygiene programmes and must have successfully completed a national written 
licensure examination as well as a state or regional clinical examination. $^{4-6}$ The licensure renewal process requires dental hygienists in all 50 states and the District of Columbia to provide evidence that they participate in continuing education activities. ${ }^{7}$

One central question in the U.S. and worldwide has always been which level of supervision dental hygienists should have. ${ }^{8}$ In the U.S., the answer to this question depends on the practice act of the state in which a dental hygienist resides and has changed over time. The first U.S. Surgeon General Report on Oral Health in the year 2000 drew attention to the fact that certain population groups in the U.S. suffer from disproportionate amounts of oral diseases and encounter severe challenges when seeking oral healthcare services. ${ }^{9}$ This nationwide discussion intensified the discussion of how dental hygienists could best contribute to improving the oral health of underserved patients and the U.S. public at large. ${ }^{10,11}$ One model that offers a constructive solution to this regulation vs access balance is the "Direct Access" Model which was first introduced in the 1980s and is today endorsed by 39 U.S. states. ${ }^{12-14}$ This model opened the doors to tremendous positive changes for the dental hygiene profession because it allows dental hygienists to initiate treatment based on their assessment of a patient's needs without specific authorization of a dentist and to treat patients without the presence of a dentist. ${ }^{13}$ While states with a direct access model differ in which treatments can be provided by dental hygienists without the supervision of a dentist, dental hygienists can now administer prophylaxis, sealants and fluoride in the majority of the 39 states that use this model. ${ }^{13}$ An overview of the changes in the required supervision of dental hygienists from 1993 to 2000 and from 2001 to 2011 carefully documented the changes in each of the 50 U.S. states concerning eleven types of services and concluded that there was a clear decrease in the needed supervision for all of these services. ${ }^{11}$

These changes plus the development of the profession of a dental therapist ${ }^{15,16}$ are promising and are likely to change how dental hygienists in the U.S. perceive their profession and their role as healthcare providers. These developments should provide a basis for increased professional pride and ambition, especially for dental hygienists who are currently in training or new to the profession. It is therefore worthwhile to explore how students who are currently enrolled in dental hygiene programmes perceive their professional role/identity, ${ }^{17-19}$ and which predictions they make for the future, that is, in the case of this study, 5 years from now. In addition, comparing students' current and future perceptions of their professional role with those of practicing registered dental hygienists $(\mathrm{RDH})$ could provide further insights into the dynamic changes of the professional identities of dental hygienists in the U.S. The objectives of this study therefore were to explore whether dental hygiene students' perceptions of their current professional identities differ (i) from the perceptions of their expected future identities, and (ii) from dental hygienists' current and (iii) past role perceptions. In consideration of the ongoing changes in the dental hygiene profession in the U.S., it is predicted that students will have more positive professional pride and ambition currently-and even more so for the future-than dental hygienists.

\section{2 | METHODS}

This study was determined to be exempt from Institutional Review Board oversight by the Institutional Review Board for the Health and Behavioral Sciences on 3rd April 2015 (\#HUM00100425).

\subsection{Respondents}

An a priori power analysis with the program package $\mathrm{G}^{*}$ Power 3.1.2 (http://www.psycho.uni-duesseldorf.de/abteilungen/aap/gpower3) was conducted to compute the needed sample size given $\alpha=.05$, the power $=.80$ and a medium effect size of .25 on a 5-point answer scale, for testing if there were significant differences between the means for the four sets of responses (students' present and future perceptions and RDHs' present and past responses). This analysis showed that a minimum of 180 respondents would be required to have the power to test the hypothesis that there were significant differences between these four sets of responses. Data were collected from 215 currently enrolled dental hygiene students in thirteen dental hygiene programmes and from 352 Registered Dental Hygienists in the State of Michigan.

\section{2 | Procedure}

In order to recruit dental hygiene students, an email was sent to the directors of the thirteen dental hygiene programmes in Michigan asking them for recruitment support. Eleven of the directors forwarded an additional recruitment email to their students. This email informed the students about the study and asked them to access an anonymous web-based survey with a web link provided in the email. A total of 189 students completed the survey online. Two programme directors printed out paper copies of the survey, informed their students in classes about the research and asked them to respond to the paper surveys. They received 32 completed paper surveys and mailed them to the research team. Six of the 221 students who completed the survey were excluded because they indicated that they were already $\mathrm{RDH}$ s at the time of the survey, resulting in a final number of 215 student surveys. Based on the total number of 2125 students enrolled during the academic year in which the study was conducted, the 215 respondents represented a $10 \%$ response rate.

For the recruitment of RDHs, a mailing list from the Michigan Department of Licensing and Regulatory Affairs was purchased, and $1200 \mathrm{RDH}$ in Michigan were identified through a computer-based random selection process. A mailing including a cover letter, the survey and a stamped return envelope was sent to these $1200 \mathrm{RDH}$. Thirteen surveys were returned as undeliverable by the postal service, and 333 anonymous paper surveys were returned through postal mail. In addition, seven dental hygienists used a web link to an anonymous web-based survey that was provided in the cover letter (total response rate $=29 \%$ ). No follow-up contact was made with these RDHs. Twelve additional web-based responses were obtained from dental hygienists who had not been recruited through the random selection process and who were members of the Michigan Dental Hygienists' Association (MDHA) who had learned about the study through their newsletter. 


\section{3 | Materials}

The survey questions were developed based on (i) a literature search and (ii) results of an analysis of essays submitted by dental hygiene students in response to a class assignment. The purpose of the literature search was to identify aspects of dental hygienists' professional role by analysing the ADHA Code of Ethics ${ }^{20}$ and other professional resources that described what is important for the professional role of a dental hygienist. $^{21-23}$ In addition, essay responses to a professional identity assignment were collected from students in the University of Michigan Dental Hygiene Classes of 2015, 2016, and 2017. These essays focused on the students' responses concerning their perceptions of what it means to be a professional dental hygienist. These open-ended responses were coded by two independent raters, and common themes were identified. These themes were then used to develop questions for a survey for dental hygiene students and a survey for RDHs in the State of Michigan.

Both surveys consisted of three sets of questions. Part 1 contained questions about the respondents' general background such as their gender, age, ethnicity, marital status and educational background as well as a question concerning their membership in the American Dental Hygienists' Association (ADHA). Part 2 consisted of questions asking the participants to rate the importance of seventeen aspects of their professional identity/role on a 5-point rating scale from 1="not at all important" to 5="very important". The dental hygiene students were asked to rate how important these aspects were for them as they studied to become Registered Dental Hygienists, and the RDHs were asked to assess the importance of these aspects in their current professional life. The dental hygiene students answered two additional questions in this section concerning the importance of their "Education and development of clinical skills" and of "Meeting the expectations of the dental hygiene program". Part 3 of the survey asked the dental hygiene students to look ahead 5 years and consider how important the same 17 aspects of their professional role would be in the future when they were RDHs; the RDHs were asked to think back to when they were students in a dental hygiene programme and indicate how important these 17 aspects were for them at this time in the past. In this section, the RDHs answered two additional questions concerning the importance of "Education and development of clinical skills" and of "Meeting the expectations of the dental hygiene program".

The first draft of the survey was pilot tested with two dental hygiene students and six RDHs. The feedback was used to finalize the survey.

\section{4 | Statistical analysis}

The paper and pencil responses to the survey for the dental hygiene students and the RDHs were entered into an SPSS data file (IBM Corp. Released 2013. IBM SPSS Statistics for Windows, Armonk, NY: IBM Corp. Version 22). The web-based survey responses were downloaded from the website as an Excel file and imported into SPSS for analysis. Descriptive statistics such as frequency distributions, percentages, measures of central tendency and variation were used to provide an overview of the findings. Four factor analyses (Extraction Method: Principal Component Analysis; Rotation Method: Varimax Rotation) were used to determine the factor structure of the four sets of professional items, namely the dental hygiene students' (i) current and (ii) prospective ratings, the RDHs' (iii) current and (iv) retrospective ratings. The factor analyses resulted in four underlying factors. Six items loaded on a first factor entitled "Professional pride," three items loaded on a second factor labelled "Work ethic," three items loaded on a third factor "Patient relations," and two items on a final factor "Professional ambition." Indices were then constructed by averaging the responses to the items that loaded on each factor and Cronbach alpha interitem consistency coefficients were computed to determine the reliability of these computed indices for each of the groups.

Inferential statistics were used to determine whether the groups differed in their background characteristics (see Table 1) and their responses to each individual item as well as the constructed indices. Chi square tests for contingency tables were used to analyse group differences in categorical variables such as gender. Independent sample $t$ tests were used for comparisons of the mean responses of dental hygiene students vs RDHs. Dependent sample t tests were used to compare the average responses of students' current vs future importance ratings and of RDHs' mean current vs retrospective responses. Univariate Analyses of Variances (ANOVAs) were used to compare the mean responses of all four sets of data. $A P<.05$ was accepted as the level of significance for all inferential tests.

\section{3 | RESULTS}

Data were collected from 215 dental hygiene students and 352 Registered Dental Hygienists (RDHs) in the State of Michigan (see Table 1). All but five of the dental hygiene students were women, while all RDHs were women. The dental hygiene students ranged in age from 20 to 50 years and the RDHs from 23 to 75 years. While 95\% of the RDHs were from European American backgrounds, $80 \%$ of the students were European American. About four of five RDHs and one of five students were married and had children.

The students represented 12 of the 13 dental hygiene programmes in the State of Michigan. Two schools offered a 3-year programme, while the other 10 schools had a 2-year programme. Sixty per cent of the dental hygiene students attended school and worked at the same time. While $24 \%$ of the students had been a dental assistant prior to starting the dental hygiene programme, $41 \%$ of the RDHs had worked as dental assistants before becoming dental hygienists. The majority of RDHs graduated from a dental hygiene programme in Michigan, with only $9 \%$ graduating from a programme outside of Michigan. They had received their dental hygiene degree between 1959 and 2015. When the RDHs were asked what their status was, $92 \%$ identified as a practicing RDH, $4 \%$ were retired, $3 \%$ were dental hygiene educators, and $2 \%$ were a dentist but had an active dental hygiene licence. Eighty-five per cent worked in clinical practice, with the years in the profession ranging from $<1$ to 55 years.

Sixty-four per cent of students were currently student members of the ADHA and that $85 \%$ of RDHs had been student members of the ADHA in the past. Only $20 \%$ of the RDHs were currently members of the ADHA, with the year of membership ranging from 0 to 53 years (see Table 1).

A clear majority of the students had very high importance ratings for the six items that loaded on the "Professional pride" factor, both 
TAB LE 1 Overview of dental hygiene students' and dental hygienists' background characteristics

\begin{tabular}{|c|c|c|}
\hline Background characteristics & $\begin{array}{l}\text { Dental hygiene } \\
\text { students } \mathrm{N}=\mathbf{2 1 5}\end{array}$ & $\begin{array}{l}\text { Registered dental } \\
\text { hygienists } \mathrm{N}=352\end{array}$ \\
\hline \multicolumn{3}{|l|}{ Gender } \\
\hline Male & $5(2 \%)$ & $0(0 \%)^{* *}$ \\
\hline Female & $210(98 \%)$ & $352(100 \%)$ \\
\hline \multicolumn{3}{|l|}{ Age } \\
\hline Mean & 24.71 & $47.55^{* * *}$ \\
\hline SD & 5.04 & 12.487 \\
\hline Range & $20-50$ & $23-75$ \\
\hline \multicolumn{3}{|l|}{ Ethnicity/race } \\
\hline European American & $170(80 \%)$ & $327(95 \%)^{* * *}$ \\
\hline Non-European American & $43(20 \%)$ & $17(5 \%)$ \\
\hline Married: Yes & $46(22 \%)$ & $281(81 \%)^{* * *}$ \\
\hline Children: Yes & 39 (18\%) & $288(82 \%)^{* * *}$ \\
\hline \multicolumn{3}{|l|}{ Year in programme } \\
\hline Sophomores & $16(8 \%)$ & $\mathrm{n} / \mathrm{a}$ \\
\hline Juniors & $91(42 \%)$ & \\
\hline Seniors & 107 (50\%) & \\
\hline $\begin{array}{l}\text { Working and going to } \\
\text { school: Yes }\end{array}$ & $128(60 \%)$ & $\mathrm{n} / \mathrm{a}$ \\
\hline $\begin{array}{l}\text { Dental assistant prior to } \\
\text { DH: Yes }\end{array}$ & $51(24 \%)$ & $144(41 \%)^{* * *}$ \\
\hline Dental hygienist status & $\mathrm{n} / \mathrm{a}$ & \\
\hline Dental hygienist & & $310(92 \%)^{a}$ \\
\hline Dental hygienist retired & & $14(4 \%)$ \\
\hline Dental hygiene educator & & $9(3 \%)$ \\
\hline $\begin{array}{l}\text { Dental hygienist and } \\
\text { now dentist }\end{array}$ & & $5(2 \%)$ \\
\hline Clinical practice: Yes & $\mathrm{n} / \mathrm{a}$ & $296(85 \%)$ \\
\hline $\begin{array}{l}\text { Years worked in dental } \\
\text { hygiene:Mean (SD)/range }\end{array}$ & $\mathrm{n} / \mathrm{a}$ & $22.99(13.18) / .05-55$ \\
\hline $\begin{array}{l}\text { Student member of ADHA: } \\
\text { Yes }\end{array}$ & $136(64 \%)$ & $282(82 \%)^{* * *}$ \\
\hline Current member of ADHA & $\mathrm{n} / \mathrm{a}$ & $70(20 \%)$ \\
\hline $\begin{array}{l}\text { Number of years in } \\
\text { ADHA:Mean (SD)/range }\end{array}$ & $\mathrm{n} / \mathrm{a}$ & $17.65(14.18) / 0-53$ \\
\hline $\begin{array}{l}\text { Leadership position in } \\
\text { ADHA: Yes }\end{array}$ & $24(11 \%)$ & $53(17 \%)$ \\
\hline
\end{tabular}

${ }^{*} P<.05 ;{ }^{* *} P<.01 ;{ }^{* * *} P<.001$.

aPercentages might not add to $100 \%$ due to rounding.

for their current as well as their future expectations of themselves (see Table 2). Overall, the students rated the importance of their future professional pride even higher than the current importance, while they attended a dental hygiene programme (on a 5-point scale with $5=$ most important: future: 4.83 vs. current: $4.77 ; P<.001)$.

No significant differences were found in the dental hygiene students' current vs future mean responses to the items loading on the "Work ethics" and on the "Patient relations" factors. For both sets of responses, the importance ratings were exceptionally high with the average ratings being between 4.90 and 4.92 on a 5-point scale. However, concerning the "Professional ambition" items, the dental hygiene students currently on average found it very important to exceed their employer's expectations and their patient's expectations and reported even higher mean ratings for the future. The same pattern of having higher importance ratings in the future were also found in the responses to the two items concerning "Advocating for the dental hygiene profession" and "Being a member of the ADHA." In both cases, the importance was rated as significantly higher for the future compared to the current time (see Table 2).

Overall, the current mean "Professional pride" and "Patient relations" responses of the RDHs were higher than the respective average retrospective responses (see Table 3). However, there were no significant differences in the importance ratings of the current and past "Work ethic" and "Professional ambition" items, with these scores being quite high for both points in time. These RDHs rated being a member of the ADHA on average higher in the past than at the current point in time.

In addition to comparing the responses of students now and for the future and the responses of RDHs now and for the past, comparisons between student and RDH responses were also conducted (see Table 4). Students in dental hygiene programmes had significantly higher average importance ratings concerning "Professional pride," "Professional ambition" and "Work ethic" and a tendency for higher scores on the "Patient relations" scale than RDHs at the present time (see Figure 1). A comparison of the responses of students at the present time and the equivalent responses of RDHs for their past when they were students in dental hygiene programmes reflects that dental hygiene students had significantly higher average overall scores for all four dimensions of their professional role than RDHs (see Figure 2). Students' future scores were significantly higher than the RDHs' present scores. Students expected that the importance of all four dimensions of their professional identity would be higher in the future when they would practice as $\mathrm{RDH}$ s than the average importance ratings of currently practicing RDHs (see Figure 3 ). The four groups differed significantly in their average importance ratings for all four indices, with students' present and future ratings being consistently higher than RDHs' ratings (see Figure 4).

\section{4 | DISCUSSION}

Dental hygienists in the U.S. live in interesting times. Currently, 39 of the 50 states in the U.S. have accepted the direct access model of care for dental hygienists ${ }^{12,13}$ and in August 2016, three states, Minnesota, Maine and Vermont, accepted the dental therapist profession and ten states were pursuing a midlevel oral healthcare work force model. ${ }^{15}$ The benefits of a direct access model for increasing care for underserved population groups in the U.S. and the public at large have been well documented by the ADHA ${ }^{12,15}$ as well as by the Health Resources and Services Administration (HRSA)'s National Center for Health Workforce Analysis. ${ }^{24,25}$ 
TAB LE 2 Dental hygiene students' importance ratings of their current and future professional expectations of themselves

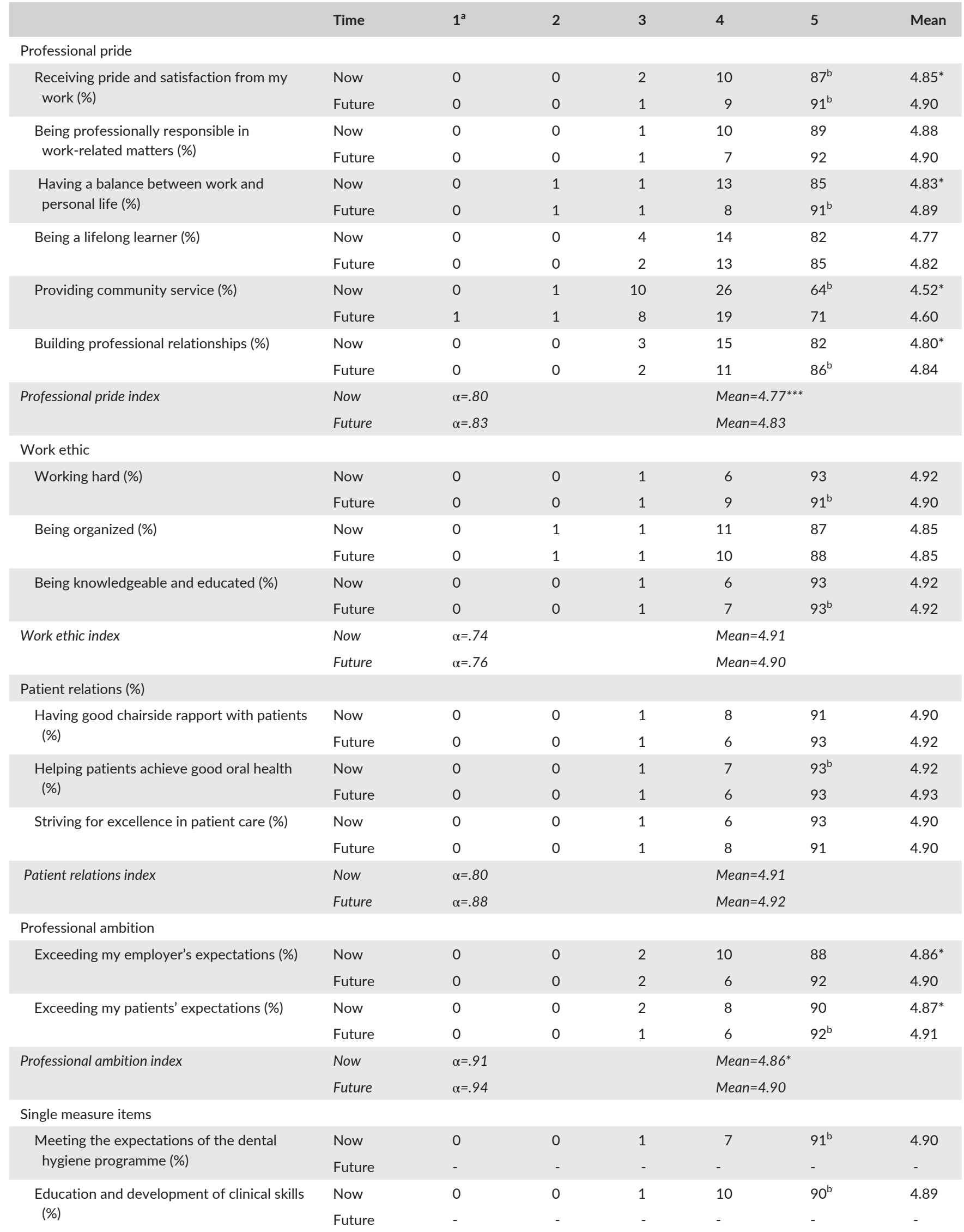


TABLE 2 (Continued)

\begin{tabular}{|c|c|c|c|c|c|c|c|}
\hline & Time & $1^{a}$ & 2 & 3 & 4 & 5 & Mean \\
\hline \multirow[t]{2}{*}{ Upholding the ADHA code of ethics (\%) } & Now & 0 & 0 & 3 & 16 & 81 & 4.78 \\
\hline & Future & 1 & 0 & 3 & 11 & 85 & 4.81 \\
\hline \multirow{2}{*}{$\begin{array}{l}\text { Advocating for the dental hygiene } \\
\text { profession (\%) }\end{array}$} & Now & 0 & 1 & 4 & 22 & $72^{b}$ & 4.65 \\
\hline & Future & 0 & 1 & 4 & 14 & $82^{\mathrm{b}}$ & 4.77 \\
\hline \multirow[t]{2}{*}{ Being a member of ADHA (\%) } & Now & 2 & 10 & 25 & 28 & 35 & 3.84 \\
\hline & Future & 2 & 5 & 15 & 23 & 55 & 4.24 \\
\hline
\end{tabular}

${ }^{a}$ The answers ranged from $1=$ Not at all important to $5=$ Very Important.

${ }^{b}$ Note that the percentages might not add to $100 \%$ due to rounding.

In addition to these developments nationwide, respondents in this study also experienced positive changes in their own state of Michigan where the Public Act No. 161 (PA 161) was approved by the legislature in 2005 as a way to expand the settings for dental hygienists to provide preventive dental hygiene services for underserved patients. ${ }^{26,27}$ Dental hygienists who want to provide services under PA 161 have to be part of a non-profit or public programme that submits an application with the Michigan Department of Community Health (MDCH) that describes the prevention programme. Programmes also need a collaborative agreement with a supervising dentist and must follow reporting requirements. A report on the activities administered by PA 161 showed that there were 55 active PA 161 programs in Michigan on 1st October 2015. ${ }^{28}$ These programmes screened 7543 adults and 40865 children, provided prophylaxis for 37288 children and 12309 adults, and applied fluoride varnish for 43489 patients between September 2014 and October $2015 .^{28}$

In consideration of these national and state developments, it is not surprising that current dental hygiene students had an exceptionally high degree of professional pride and expected to have even a higher level of pride and professional ambition in the future. The fact that the current mean importance ratings of professional pride and ambition of current RDHs were significantly lower than those of current students might lead to the assumption that a loss of idealism occurred over the course of their professional lifespan. However, a comparison of RDHs' current and past ratings showed that their past ratings were less favourable on average than their current ratings. This finding combined with dental hygiene students' more positive current and future ratings can be interpreted as a sign of realistic optimism for the profession: positive changes are occurring and reflect positive results for underserved patients and the public, encouraging dental hygiene students and RDHs to embrace the profession with pride, ambition, a very strong sense of work ethic, and an exceptionally high importance being placed on excellent patient relations.

While the data presented in this study were from the U.S. only, the argument can be made that a discussion of professional identity perceptions of dental hygienists is of general interest and importance. The items developed in this study could therefore be used by researchers in other countries as well. A cross-cultural comparison might provide a deeper understanding of how historical as well as structural and political conditions affect dental hygienists' perceptions of their professional identity and in turn their professional lives.
This research had several limitations. First, this study had a crosssectional design. Students and RDHs did not only rate the importance of the four components of their professional identity for the current time, but also considered future importance ratings in the case of students and retrospective ratings in the case of RDHs. While a longitudinal study would have obviously assessed change over time more concretely, the cross-sectional character forces us to consider that retrospective biases in the case of RDHs and youthful optimism in the case of the students' might have biased the responses. Future research should therefore focus on longitudinal studies of professional role perceptions. Second, while the power analysis showed that the sample size in this study was sufficient to test the hypotheses of interest, it did not allow conducting subgroup analyses. For example, given that only $20 \%$ of the RDHs were ADHA members, the sample size was too small to test whether the mean responses of ADHA members vs non-members differed significantly. Future research should therefore seek the financial support necessary to recruit more RDHs into the study so that subgroup analyses will be possible. Third, these data were collected in one state in the U.S. A national survey that could allow comparing responses of dental hygiene students and dental hygienists in states with vs without a direct access model and with vs without a midlevel provider model could shed further light on the way students and practicing dental hygienists consider their professional roles as a function of their political and social environment.

\section{5 | CONCLUSIONS}

This study offers the first research findings concerning dental hygiene students' current and future professional role perceptions as well as RDHs' current and past perceptions in the U.S. The results show the exceptionally high level of importance that both students and dental hygienists place on professional pride, work ethic, patient relations and professional ambition.

A comparison of the students' and clinicians' current ratings showed that students place an even higher importance on these aspects of their professional identity than practitioners. These differences should not be interpreted as a loss of idealism. Instead a comparison of the dental hygienists' past and current ratings shows that dental hygienists are more positive now than they remember 
TABLE 3 Registered dental hygienists' importance ratings of their current versus past professional expectations

\begin{tabular}{|c|c|c|c|c|c|c|c|}
\hline & Time & $1^{\mathrm{a}}$ & 2 & 3 & 4 & 5 & Mean \\
\hline \multicolumn{8}{|l|}{ Professional pride } \\
\hline $\begin{array}{l}\text { Receiving pride and satisfaction from my } \\
\text { work (\%) }\end{array}$ & Past & 1 & 0 & 6 & 20 & 73 & $4.63^{* *}$ \\
\hline \multirow{2}{*}{$\begin{array}{l}\text { Being professionally responsible in } \\
\text { work-related matters (\%) }\end{array}$} & Past & 1 & 0 & 7 & 20 & 72 & $4.63^{* * *}$ \\
\hline & Now & 0 & 0 & 2 & 15 & $84^{b}$ & 4.82 \\
\hline $\begin{array}{l}\text { Having a balance between work and } \\
\text { personal life (\%) }\end{array}$ & Now & 0 & 1 & 4 & 16 & $80^{b}$ & 4.75 \\
\hline \multirow[t]{2}{*}{ Being a lifelong learner (\%) } & Past & 2 & 2 & 13 & 25 & $59^{\mathrm{b}}$ & $4.37^{* * *}$ \\
\hline & Now & 0 & 1 & 4 & 28 & $68^{\mathrm{b}}$ & 4.62 \\
\hline \multirow[t]{2}{*}{ Providing community service (\%) } & Past & 5 & 8 & 28 & 22 & $36^{b}$ & 3.76 \\
\hline & Now & 3 & 8 & 24 & 36 & $28^{b}$ & 3.79 \\
\hline Professional pride index & Now & $\alpha=.73$ & & & & Mear & \\
\hline \multicolumn{8}{|l|}{ Work ethic } \\
\hline \multirow[t]{2}{*}{ Working hard (\%) } & Past & 0 & 0 & 3 & 14 & $83^{b}$ & $4.80^{*}$ \\
\hline & Now & 1 & 0 & 6 & 15 & $79^{\mathrm{b}}$ & 4.70 \\
\hline \multirow[t]{2}{*}{ Being organized (\%) } & Past & 0 & 1 & 6 & 15 & 78 & 4.70 \\
\hline & Now & 0 & 0 & 2 & 18 & $80^{b}$ & 4.76 \\
\hline \multirow[t]{2}{*}{ Being knowledgeable and educated (\%) } & Past & 0 & 0 & 1 & 14 & 85 & $4.83^{*}$ \\
\hline & Now & 0 & 0 & 1 & 9 & 90 & 4.89 \\
\hline $\begin{array}{l}\text { Helping patients achieve good oral health } \\
\text { (\%) }\end{array}$ & Now & 0 & 0 & 0 & 16 & $83^{b}$ & 4.82 \\
\hline \multirow[t]{2}{*}{ Striving for excellence in patient care (\%) } & Past & 0 & 0 & 3 & 16 & $82^{b}$ & 4.79 \\
\hline & Now & 1 & 0 & 1 & 12 & $87^{b}$ & 4.84 \\
\hline \multirow[t]{2}{*}{ Patient relations index } & Past & $\alpha=.76$ & & & & Mear & \\
\hline & Now & $\alpha=.75$ & & & & Mear & \\
\hline \multicolumn{8}{|l|}{ Professional ambition } \\
\hline \multirow[t]{2}{*}{ Exceeding my employer's expectations (\%) } & Past & 0 & 2 & 7 & 25 & 66 & 4.55 \\
\hline & Now & 1 & 1 & 6 & 34 & 58 & 4.48 \\
\hline \multirow[t]{2}{*}{ Exceeding my patients' expectations (\%) } & Past & 0 & 1 & 6 & 21 & 72 & $4.65^{*}$ \\
\hline & Now & 0 & 0 & 2 & 22 & 76 & 4.73 \\
\hline \multirow[t]{2}{*}{ Professional ambition index } & Past & $\alpha=.80$ & & & & Mear & \\
\hline & Now & $\alpha=.74$ & & & & Mear & \\
\hline Single measure items & & & & & & & \\
\hline Meeting the expectations of the dental & Past & 0 & 0 & 1 & 12 & 87 & 4.86 \\
\hline hygiene programme (\%) & Now & - & - & - & - & - & - \\
\hline Education and development of clinical skills & Past & 0 & 0 & 3 & 16 & 81 & 4.78 \\
\hline (\%) & Now & - & - & - & - & - & - \\
\hline
\end{tabular}


TABLE 3 (Continued)

\begin{tabular}{|c|c|c|c|c|c|c|c|}
\hline & Time & $1^{a}$ & 2 & 3 & 4 & 5 & Mean \\
\hline \multirow[t]{2}{*}{ Upholding the ADHA code of ethics (\%) } & Past & 2 & 2 & 7 & 19 & $71^{b}$ & 4.55 \\
\hline & Now & 2 & 2 & 7 & 17 & $73^{b}$ & 4.58 \\
\hline \multirow{2}{*}{$\begin{array}{l}\text { Advocating for the dental hygiene } \\
\text { profession (\%) }\end{array}$} & Past & 5 & 8 & 24 & 22 & 41 & 3.87 \\
\hline & Now & 4 & 8 & 26 & 29 & $32^{b}$ & 3.77 \\
\hline \multirow[t]{2}{*}{ Being a member of ADHA (\%) } & Past & 16 & 8 & 22 & 24 & $29^{b}$ & $3.46^{* * *}$ \\
\hline & Now & 24 & 25 & 28 & 9 & $15^{\mathrm{b}}$ & 2.66 \\
\hline
\end{tabular}

${ }^{\text {a }}$ The answers ranged from $1=$ Not at all important to $5=$ Very Important.

${ }^{b}$ Note that the percentages might not add to $100 \%$ due to rounding.

TAB LE 4 Dental hygiene students' average current versus future and registered dental hygienists' past versus current professional expectations

\begin{tabular}{|c|c|c|c|c|}
\hline & $\begin{array}{l}\text { Students } \\
\text { now }\end{array}$ & $\begin{array}{l}\text { RDHs } \\
\text { past }\end{array}$ & $\begin{array}{l}\text { Students } \\
\text { future }\end{array}$ & RDHs now \\
\hline \multicolumn{5}{|l|}{ Professional pride } \\
\hline $\begin{array}{l}\text { Receiving pride and satisfaction from my } \\
\text { work }\end{array}$ & 4.85 & 4.65 & 4.90 & $4.75^{a, b, c, d}$ \\
\hline $\begin{array}{l}\text { Being professionally responsible in } \\
\text { work-related matters }\end{array}$ & 4.88 & 4.63 & 4.90 & $4.82^{a, c, d}$ \\
\hline $\begin{array}{l}\text { Having a balance between work and } \\
\text { personal life }\end{array}$ & 4.83 & 4.06 & 4.89 & $4.74^{\mathrm{a}, \mathrm{b}, \mathrm{c}, \mathrm{d}}$ \\
\hline Being a lifelong learner & 4.77 & 4.37 & 4.82 & $4.63^{\mathrm{a}, \mathrm{b}, \mathrm{c}, \mathrm{d}}$ \\
\hline Providing community service & 4.52 & 3.77 & 4.60 & $3.80^{\mathrm{a}, \mathrm{b}, \mathrm{c}, \mathrm{d}}$ \\
\hline Building professional relationships & 4.80 & 4.05 & 4.84 & $3.96^{\mathrm{a}, \mathrm{b}, \mathrm{c}, \mathrm{d}}$ \\
\hline Professional pride index & 4.77 & 4.24 & 4.83 & $4.45^{\mathrm{a}, \mathrm{b}, \mathrm{c}, \mathrm{d}}$ \\
\hline \multicolumn{5}{|l|}{ Work ethics } \\
\hline Working hard & 4.92 & 4.80 & 4.90 & $4.71^{\mathrm{a}, \mathrm{b}, \mathrm{c}, \mathrm{d}}$ \\
\hline Being organized & 4.85 & 4.70 & 4.85 & $4.77^{\mathrm{a}, \mathrm{c}, \mathrm{d}}$ \\
\hline Being knowledgeable and educated & 4.92 & 4.84 & 4.92 & $4.89^{\mathrm{a}, \mathrm{d}}$ \\
\hline Work ethic index & 4.91 & 4.78 & 4.90 & $4.79^{a, b, c, d}$ \\
\hline \multicolumn{5}{|l|}{ Patient relations } \\
\hline Having good chairside rapport with patients & 4.90 & 4.65 & 4.92 & $4.90^{\mathrm{a}, \mathrm{d}}$ \\
\hline Helping patients achieve good oral health & 4.92 & 4.73 & 4.93 & $4.82^{\mathrm{a}, \mathrm{b}, \mathrm{c}, \mathrm{d}}$ \\
\hline Striving for excellence in patient care & 4.90 & 4.79 & 4.90 & $4.84^{\mathrm{a}, \mathrm{d}}$ \\
\hline Patient relations index & 4.91 & 4.73 & 4.92 & $4.85^{\mathrm{a}, \mathrm{c}, \mathrm{d}}$ \\
\hline \multicolumn{5}{|l|}{ Professional ambition } \\
\hline Exceeding my employer's expectations & 4.86 & 4.55 & 4.90 & $4.47^{\mathrm{a}, \mathrm{b}, \mathrm{c}, \mathrm{d}}$ \\
\hline Exceeding my patients' expectations & 4.87 & 4.64 & 4.91 & $4.74^{a, b, c, d}$ \\
\hline Professional ambition Index & 4.86 & 4.60 & 4.90 & $4.61^{\mathrm{a}, \mathrm{b}, \mathrm{c}, \mathrm{d}}$ \\
\hline \multicolumn{5}{|l|}{ Single item measures } \\
\hline Being a member of ADHA & 3.84 & 3.43 & 4.24 & $2.66^{\mathrm{a}, \mathrm{b}, \mathrm{c}, \mathrm{d}}$ \\
\hline Upholding the ADHA Code of Ethics & 4.78 & 4.56 & 4.81 & $4.58^{\mathrm{a}, \mathrm{b}, \mathrm{c}, \mathrm{d}}$ \\
\hline $\begin{array}{l}\text { Advocating for the dental hygiene } \\
\text { profession }\end{array}$ & 4.65 & 3.87 & 4.77 & $3.77^{\mathrm{a}, \mathrm{b}, \mathrm{c}, \mathrm{d}}$ \\
\hline Education and development of clinical skills & 4.89 & $4.78 d$ & - & - \\
\hline $\begin{array}{l}\text { Meeting the expectations of the dental } \\
\text { hygiene programme }\end{array}$ & 4.90 & 4.86 & - & - \\
\hline
\end{tabular}

${ }^{a}$ Significant difference between all four groups at $P>.05$.

${ }^{b}$ Significant difference between students now and RDH now at $P>05$.

'Significant difference between students future and RDH now at $P>05$.

dSignificant difference between "Students now" and "RDH past" at $P>.05$. 
4.8

4.7

4.6

4.5

4.4

4.3

4.2
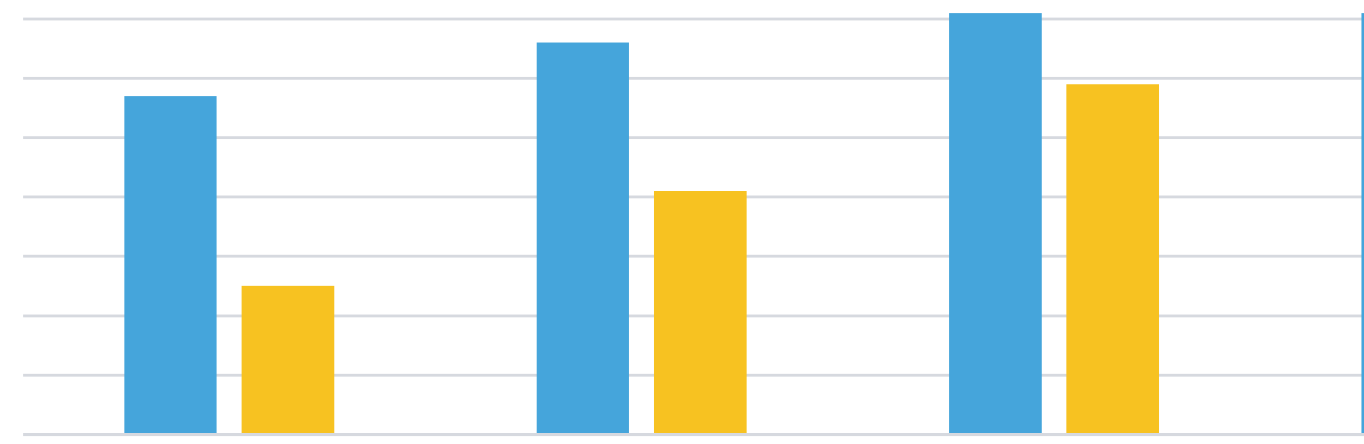

Professional pride

Professional

Work ethic $P<.001$

ambition $P<.001$

$P<.001$
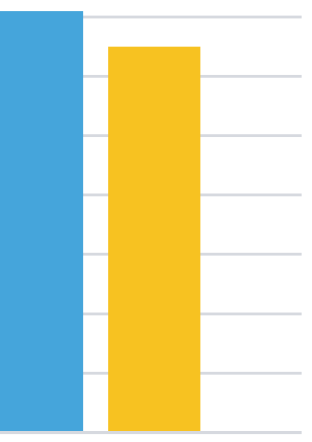

Patient relations

$$
P=.065
$$

\section{Students Now RDH Now}

FIGURE 1 The importance ratings ranged from 1="not at all important" to 5="very important"

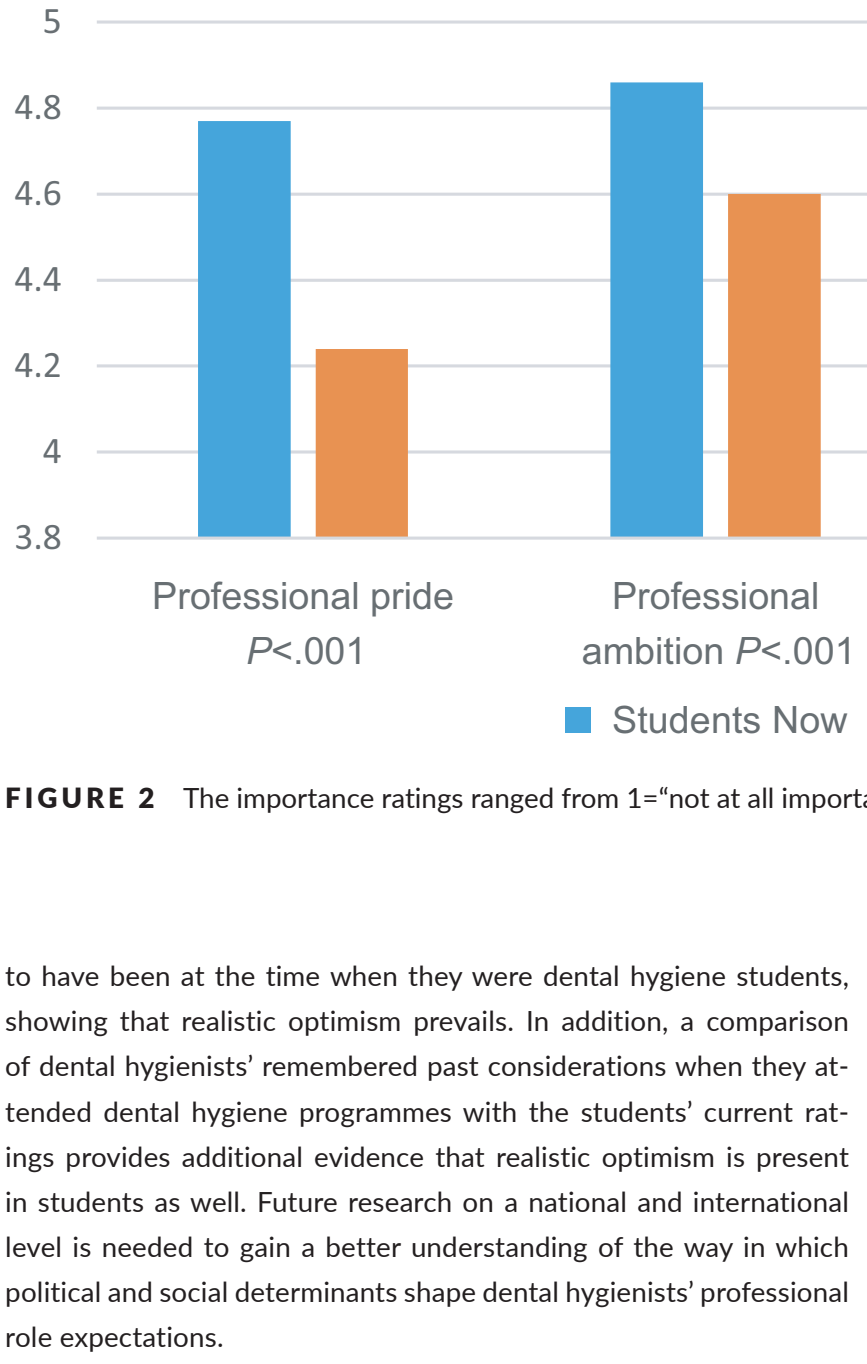

\section{CLINICAL RELEVANCE}

\section{1 | Scientific rational}

While dental hygienists in the U.S. have worked under direct, indirect or general supervision of dentists since the 19th century, current professional efforts aim at establishing direct access models and the dental therapist profession. How do these changes affect dental hygiene students' and clinicians' perceptions of their professional identity? 


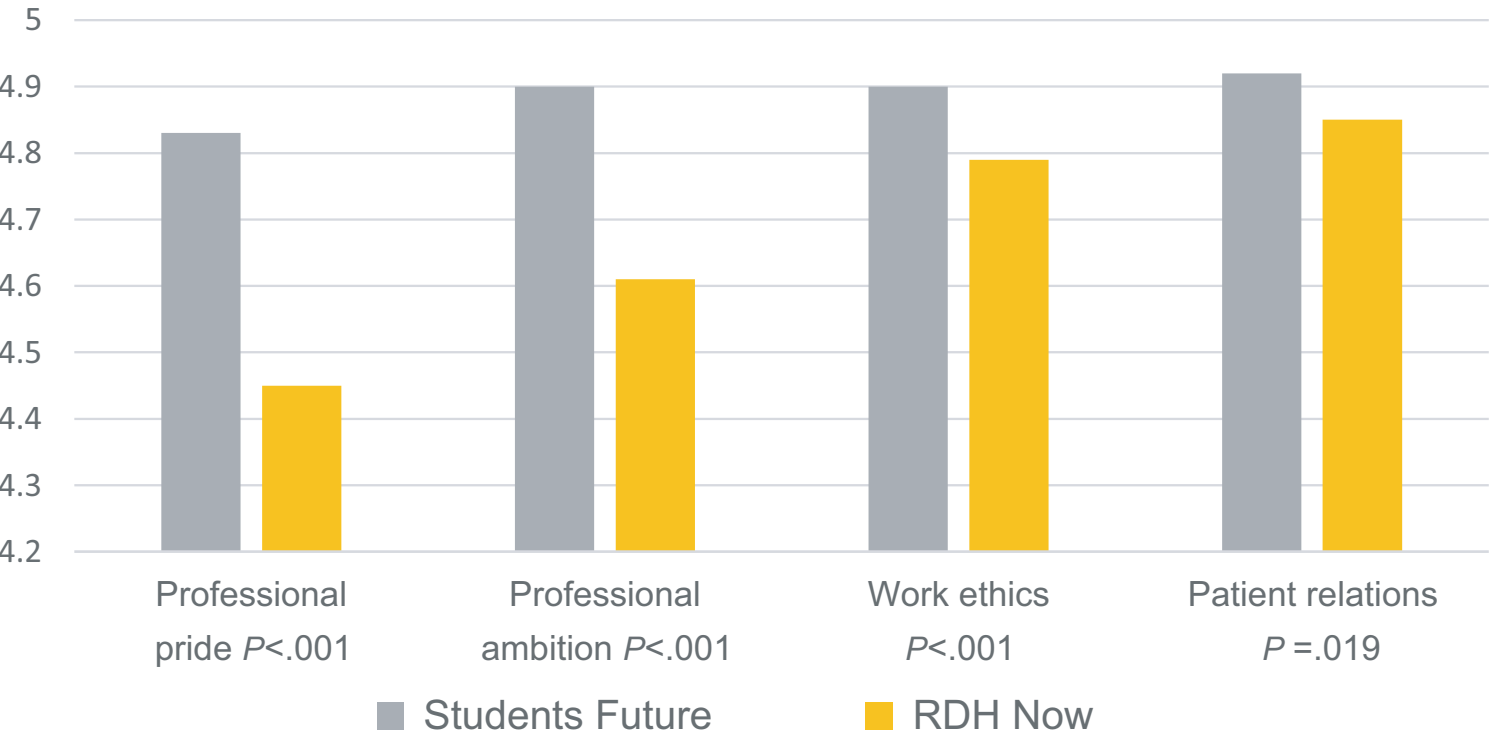

FIGURE 3 The importance ratings ranged from 1="not at all important" to 5="very important"

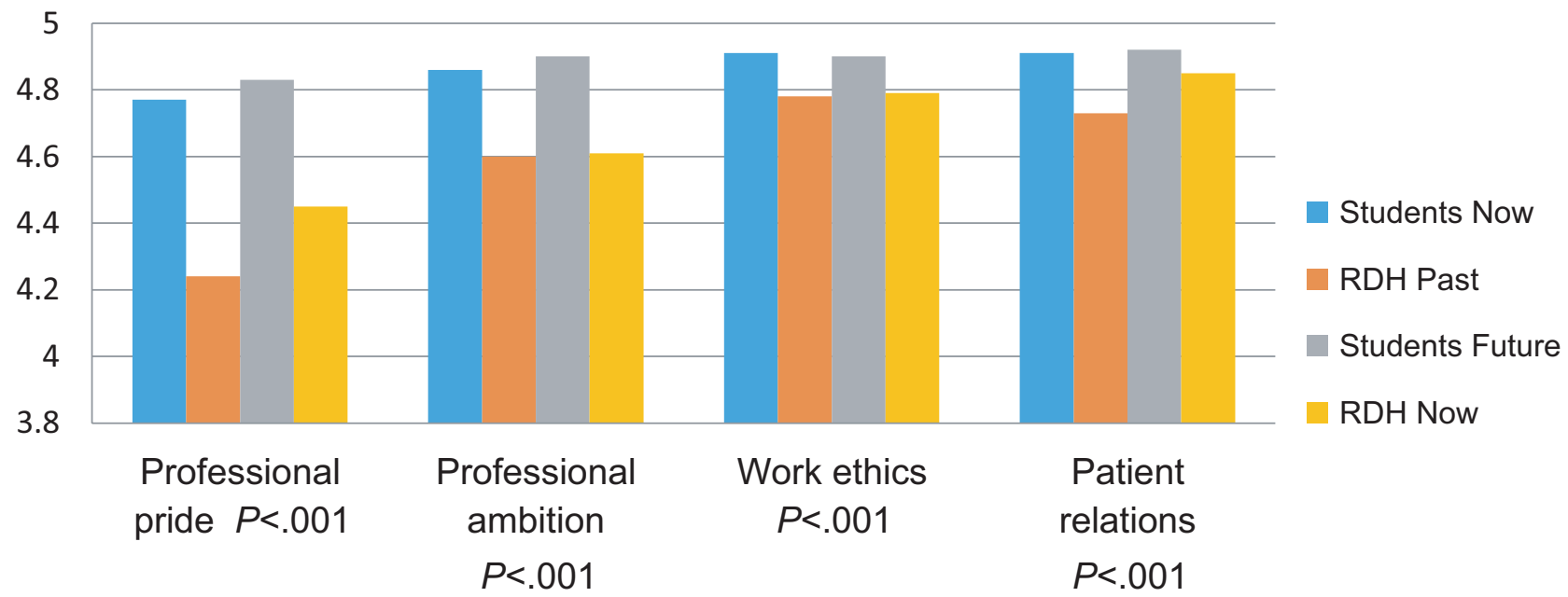

FIGURE 4 The importance ratings ranged from 1="not at all important" to 5="very important"

\section{2 | Principal findings}

A cross-sectional analysis of students' current vs future and dental hygienists' past vs. current professional role perceptions finds realistic optimism in these times of change in the U.S.

\section{3 | Practical implications}

Educational efforts are needed to prepare students and practicing dental hygienists for the future of their profession in the U.S.

\section{ACKNOWLEDGEMENTS}

We want to thank Professor Anne Gwozdek for her work with Professor Kinney in developing the professional identity assignment at the University of Michigan utilized within this research project. We want to thank Dr. Taichman for her contributions to the methodological aspects of this research and the University of Michigan-Rackham Graduate programme for a Student Research Grant and Research Block Grant to the first author.

\section{REFERENCES}

1. Reitz M, Jadegja A. The collaborative study of dental hygiene. Int J Dent Hygiene. 2004;2:36-39.

2. Nathe CN. Dental Public Health and Research: Contemporary Practice for the Dental Hygienist, 3rd edn. Chapter 2. Upper Saddle River, NJ: Pearson Education, Inc; 2011.

3. Fones AC. The origin and history of the dental hygienists. J Dent Hyg. 2013;87S1:58-62. 
4. American Dental Association Commission on Dental Accreditation. Chicago, IL: American Dental Association Commission on Dental Accreditation; c2016. Search for a dental program [Internet]. http://www.ada.org/en/coda/find-a-program/searchdental-programs\#t=us\&sort=\%40codastatecitysort\%20ascending\&f: ProgramName=[Dental\%20Hygien. Accessed December 10, 2016.

5. American Dental Hygienists' Association. Chicago, IL: American Dental Hygienists' Association; c2012-2015 ADHA.org. Important facts about dental hygienists [Internet]. http://www.adha.org/licensure. Accessed December 2, 2016.

6. Gibson-Howell JC, Hicks MJ. Dental hygienists' role in patient assessments and clinical examinations in U.S. dental practices: a review of the literature. J Allied Health. 2010;39:e1-e5.

7. American Dental Hygienists' Association. Chicago, IL: American Dental Hygienists' Association; c2012-2015 ADHA.org. States requiring continuing education for licensure renewal [Internet]. http:// www.adha.org/resources-docs/7512_CE_Requirements_by_State. pdf. Accessed December 2, 2016.

8. American Dental Hygienists' Association. Chicago, IL: American Dental Hygienists' Association; c2012-2015 ADHA.org. Dental hygiene practice act overview: permitted functions and supervision levels by State [Internet]. https://www.adha.org/resources-docs/7511_Permitted Services_Supervision_Levels_by_State.pdf. Accessed December 2, 2016

9. U.S. Department of Health and Human Services. Oral health in America: a report of the surgeon general [Internet]. Rockville, MD: U.S. Department of Health and Human Services, National Institute of Dental and Craniofacial Research, National Institutes of Health. https://www.nidcr.nih.gov/DataStatistics/SurgeonGeneral/ Documents/hck1ocv.@www.surgeon.fullrpt.pdf. Updated 2000 September; Accessed February 1, 2011.

10. American Dental Hygienists' Association (ADHA). Chicago, IL: American Dental Hygienists' Association; c2012-2015 ADHA.org. Facts about the dental hygiene workforce in the United States. http:// www.adha.org/resources-docs/75118_Facts_About_the_Dental Hygiene_Workforce.pdf. Accessed December 2, 2016

11. Catlett AV, Greenlee R. A retrospective comparison of dental hygiene supervision changes from 2001 to 2011. J Dent Hyg. 2013;87:110-117.

12. American Dental Hygienists' Association (ADHA). Chicago, IL: American Dental Hygienists' Association; c2012-2015 ADHA. org. Direct access [Internet]. http://www.adha.org/direct-access. Accessed November 13, 2016.

13. American Dental Hygienists'Association (ADHA). Chicago, IL:American Dental Hygienists' Association; c2012-2015 ADHA.org. Direct access States [Internet]. http://www.adha.org/resources-docs/7513_Direct Access_to_Care_from_DH.pdf. Accessed December 2, 2016.

14. American Dental Hygienists' Association (ADHA). Chicago, IL: American Dental Hygienists' Association; c2012-2015 ADHA.org. Direct access 2016 [Internet]. http://www.adha.org/resources-docs/7524_Current Direct_Access_Map.pdf. Accessed December 2, 2016.

15. American Dental Hygienists' Association (ADHA). Chicago, IL: American Dental Hygienists' Association; c2012-2015 ADHA org. Expanding access to care through mid-level oral health practitioners [Internet]. https://www.adha.org/resources-docs/
Expanding_Access_to_Care_through_Mid-Level_Oral_Health_ Practitioners_08-16.pdf. Accessed December 2, 2016.

16. Minnesota Department of Health Minnesota Board of Dentistry Report to the Minnesota Legislature 2014. Early impacts of dental therapists in Minnesota http://www.health.state.mn.us/divs/orhpc/ workforce/dt/dtlegisrpt.pdf. Accessed December 2, 2016.

17. Worthington M, Salamonson $Y$, Weaver R, Cleary M. Predictive validity of the Macleod Clark Professional Identity Scale for undergraduate nursing students. Nurse Educ Today. 2013;33:187-191.

18. Adams K, Hean S, Sturgis P. Investigating the factors influencing professional identity of first-year health and social care students. Learn Heal Soc Care. 2006;5:55-68.

19. Brennan MD, Monson V. Professionalism: good for patients and health care organizations. Mayo Clin Proc. 2014;89:644-652.

20. American Dental Hygienists' Association. Chicago, IL: American Dental Hygienists' Association; c2012-2015 ADHA.org. ADHA bylaws and code of ethics [Internet]. http://www.adha.org/resources-docs/7611_ Bylaws_and_Code_of_Ethics.pdf. Accessed December 2, 2016.

21. Beemsterboer PL. Ethics and Law in Dental Hygiene. 2nd ed. St. Louis (MO): Saunders Elsevier; 2009. Chapter 1, Ethics and professionalism; p 3-21.

22. American Dental Hygienists' Association. Standards of Clinical Dental Hygiene Practice. Chicago, IL: American Dental Hygienists' Association; 2014:16.

23. Association American Dental Education. ADEA statement on professionalism in dental education. J Dent Educ. 2009;73:860-865.

24. Health Resources and Services Administration, The professional practice environment of dental hygienists in the fifty states and the District of Columbia, 2001.

25. National Center for Health Workforce Analysis. Nursing Aides, Home Health Aides, and Related Health Care Occupations -- National and Local Workforce Shortages and Associated Data Needs. Bureau of Health Professions, Rockville, MD, 2004.

26. Pervez A, Kinney J, Gwozdek A, Farrell CM, Inglehart MR. Michigan's PA 161 Public dental prevention program: dental and dental hygiene students', faculty and licensed hygienists' educational experiences, knowledge, attitudes, and interests. J Dent Educ. 2016;80:1071-1081.

27. 93rd legislature. Act No. 161: Public Acts of 2005 [Internet]. Lansing, MI: Michigan Legislature. http://www.legislature.mi.gov/documents/ 2005-2006/publicact/htm/2005-PA-0161.htm. Accessed December 2, 2015.

28. Michigan Dental Community Health - Oral Health Program. PA 161 Program [Internet]. Lansing, MI: The official state of Michigan web site Michigan.gov. http://www.michigan.gov/documents/mdhhs/PA161-AnnualReport15_537454_7.pdf. Accessed December 2, 2016.

How to cite this article: Champine JM, Inglehart MR, Furgeson $\mathrm{D}$, et al. Loss of idealism or realistic optimism? A cross-sectional analysis of dental hygiene students' and registered dental hygienists' professional identity perceptions. Int J Dent Hygiene. 2018;16:114-124. https://doi.org/10.1111/idh.12287 